\title{
THE EFFECT OF EO AND STEAM STERILIZATION ON THE MECHANICAL AND ELECTROCHEMICAL PROPERTIES OF TITANIUM GRADE 4
}

\author{
VPLIV EO IN STERILIZACIJE S PARO NA MEHANSKE IN \\ ELEKTROKEMIJSKE LASTNOSTI TITANA GRADE 4
}

\author{
Marcin Basiaga, Witold Walke, Zbigniew Paszenda, Anita Kajzer \\ Silesian University of Technology, Faculty of Biomedical Engineering, Zabrze, Poland \\ marcin.basiaga@polsl.pl
}

Prejem rokopisa - received: 2014-09-23; sprejem za objavo - accepted for publication: 2015-03-09

doi:10.17222/mit.2014.241

\begin{abstract}
Currently, various modifications to surfaces are made more and more frequently in order to improve implants' haemocompatibility. The main criterion determining the applicability of the respective surface-modification method is obtaining a product featuring suitable functional properties. These properties depend to a great extent on the corrosion resistance in the environment of human blood. Subject-matter literature does not devote much attention to the sterilisation process for titanium and $\mathrm{cpTi}$ alloys with surface modifications. A problem that still remains unsolved is the selection of a proper test showing the full characteristics of their behaviour contact with a blood environment during the time that the implant is used. Therefore, the authors of this study made an attempt to evaluate the impact of medical sterilisation methods, i.e., the ethylene oxide anodic oxide and $\mathrm{SiO}_{2}$ layer, by means of the sol-gel method. The efficiency of the suggested technology for oxide layer application was evaluated on the basis of mechanical and electrochemical tests. Sterilisation in ethylene oxide and steam had a favourable influence on the electrochemical and mechanical properties of cpTi, irrespective of the method of surface preparation. In order to simulate real conditions, the tests were performed in artificial plasma at a temperature of $T=37 \pm 1^{\circ} \mathrm{C}$ and $\mathrm{pH}=7.0 \pm 0.2$. The results proved the diversification of electrochemical properties of the oxide layers, depending on the technological parameters of its application. The suggestion of proper variants of the surface modification with the application of electrochemical and chemical methods is of long-range importance and will contribute to the development of technological conditions with specific parameters for the creation of oxide layers on metallic implants made of cpTi.

Keywords: cpTi (Grade 4), $\mathrm{SiO}_{2}, \mathrm{TiO}_{2}$, mechanical properties, electrochemical properties
\end{abstract}

Vedno pogosteje se opravljajo različne modifikacije površine, da bi se izboljšala hemokompatibilnost vsadkov. Glavni kriterij, ki določa uporabnost metode za modifikacijo površine je, da proizvod pokaže primerne funkcionalne lastnosti. Te lastnosti so v veliki meri odvisne od korozijske odpornosti v človeški krvi. Obstoječa literatura ne posveča velike pozornosti postopku sterilizacije titana in cpTi zlitin z modificirano površino. Problem, ki še ni rešen, je izbira primernega preizkusa, ki bi pokazal vse značilnosti o obnašanju stika s krvjo med uporabo vsadka. Zato so avtorji v tej študiji poizkusili oceniti vpliv medicinskih metod sterilizacije, kot je etilen oksid anodni oksid in $\mathrm{SiO}_{2}$ plast izdelano s pomočjo metode sol-gel. Predlagana tehnologija uporabe oksidnega sloja je bila ocenjena $\mathrm{z}$ mehanskimi in elektrokemijskimi preizkusi. Sterilizacija $\mathrm{v}$ etilen oksidu in pari je imela ugodne vplive na elektrokemijske in mehanske lastnosti cpTi, ne glede na način priprave površine. Za simulacijo realnih pogojev so bili preizkusi izvršeni v umetni plazmi pri temperaturi $T=37 \pm 1^{\circ} \mathrm{C}$ in $\mathrm{pH}=7,0 \pm 0,2$. Dobljeni rezultati so potrdili različnost v elektrokemijskih lastnostih oksidnih plasti, odvisno od tehnoloških parametrov njene uporabe. Predlog ustreznega načina spremembe površine z uporabo elektrokemijskih in kemijskih metod je dolgoročno pomemben in bo prispeval k razvoju tehnoloških pogojev s specifičnimi parametri nastajanja plasti oksidov na kovinskem implantatu iz cpTi.

Ključne besede: cpTi (Grade 4), $\mathrm{SiO}_{2}, \mathrm{TiO}_{2}$, mehanske lastnosti, elektrokemijske lastnosti

\section{INTRODUCTION}

Literature does not devote much attention to the sterilisation process for titanium and cpTi alloys with surface modification. ${ }^{1,2}$ In recent years there has been a dynamic development in pure titanium coating methods, aimed at improving the hemocompatibility. ${ }^{3,4}$ Surface-layer modification methods must be selected in a way that does not cause phase or structural transitions, or precipitation processes in the base material. It has a particular significance for the geometry of implants having small cross-sectional areas or small-radii edges (stents or heart valves). For this reason, surface-layer modification for titanium and its alloys uses low-temperature methods, and especially anodic oxidation coating and the sol-gel method. The properties of $\mathrm{TiO}_{2}$ layers obtained through the process of anodic oxidation and $\mathrm{SiO}_{2}$ layers obtained with the sol-gel method depend on the properties of the titanium surface and the process parameters. The development and verification of conditions for coating cpTi with layers of $\mathrm{TiO}_{2}$ and $\mathrm{SiO}_{2}$ characterized by high hemocompatibility was the topic of previous papers published by the authors. ${ }^{5-7}$ The safety of a medical device involving contact with blood is also related to the necessity of observing the appropriate procedures, preventing the transfer of pathogenic microorganisms into the human body. Such procedures are aimed at the removal and efficient elimination of microorganisms and the obtaining of sterile medical devices complying with certain specified quality requirements. A medical device is considered sterile when it achieves a Sterility Assur- 
ance Level (SAL) of $10^{-6}$. Therefore, in order to determine the impact of the procedure on the properties of the proposed surface layers, the authors subjected cpTi samples to steam sterilization and ethylene oxide sterilization. These two methods of medical sterilization are currently the most frequently used for devices having contact with blood. Taking the sterilization process into consideration will allow the characterization of the physical and chemical properties of the proposed surface layers in a more complete way, which has a significant influence on reducing the incidence of failures in the treatment of cardiovascular diseases.

\section{MATERIALS AND METHODS}

The study material was Grade $4 \mathrm{cpTi}$ in the form of disks of the following dimensions: diameter, $d=14 \mathrm{~mm}$, thickness, $g=2 \mathrm{~mm}$. The samples were subjected to metal finishing consisting of mechanical grinding and electrolytic polishing, and then coating with layers of $\mathrm{SiO}_{2}$ and $\mathrm{TiO}_{2}$ based on two methods. The $\mathrm{SiO}_{2}$ layer was applied using the sol-gel method with the following process parameters: $v=3.0 \mathrm{~cm} / \mathrm{min}, T=430{ }^{\circ} \mathrm{C}, t=60$ min. The silica precursors were: tetraethyl orthosilicate (TEOS), $\mathrm{Si}\left(\mathrm{OC}_{2} \mathrm{H}_{5}\right)_{4}$ and tetramethyl orthosilicate (TMOS), $\mathrm{Si}\left(\mathrm{OCH}_{3}\right)_{4}$. Other reagents included ethyl alcohol (EtOH) and water. On the other hand, the $\mathrm{TiO}_{2}$ layer was applied with the use of anodic oxidation at a potential of $100 \mathrm{~V}$ in an electrolyte based on phosphoric and sulphuric acids. Later, the prepared samples were subjected to ethylene oxide sterilization and steam sterilization. Ethylene oxide sterilization was conducted during a 12-hour cycle of exposure to ethylene oxide at $30{ }^{\circ} \mathrm{C}$. After the process, the samples were ventilated for $2 \mathrm{~h}$ with the use of an EOGas series sterilizer from Andersen Products. The cycle yielded a Sterility Assurance Level SAL of $10^{-6}$. The process was controlled by means of a chemical indicator, a biological indicator and an ethylene oxide exposure indicator. The steam sterilization was performed in a Basic Plus autoclave at temperature, $T=134{ }^{\circ} \mathrm{C}$, pressure, $p=2.1 \mathrm{bar}$, and time, $t=12$ $\min$.

The tests were performed on samples coated with $\mathrm{SiO}_{2}$ and $\mathrm{TiO}_{2}\left(\mathrm{cpTi}+\mathrm{SiO}_{2}\right.$ and $\left.\mathrm{cpTi}+\mathrm{TiO}_{2}\right)$, coated with $\mathrm{SiO}_{2}$ and $\mathrm{TiO}_{2}$ and subjected to steam sterilization (cpTi+SiO ${ }_{2}+$ steam and cpTi+ $\mathrm{TiO}_{2}+$ steam), and coated with $\mathrm{SiO}_{2}$ and $\mathrm{TiO}_{2}$ and subjected to ethylene oxide sterilization (cpTi+ $\mathrm{SiO}_{2}+\mathrm{EO}$ and $\left.\mathrm{cpTi}+\mathrm{TiO}_{2}+\mathrm{EO}\right)$. In order to assess the impact of a given type of medical sterilization on the mechanical and electrochemical properties of the proposed cpTi surface modifications, the authors selected electrochemical potentiodynamic and impedance tests. The assessment of the mechanical properties, in turn, consisted of a measurement of the layer adhesion to the base and a measurement of the hardness.

The investigation of the electrochemical properties began with potentiodynamic tests and registration of the polarization curves. The measurement facility consisted of a potentiostat with a PGP-201 generator, an electrochemical cell with a set of electrodes (platinum PtP-201 electrode the auxiliary and calomel electrode as the reference), and a solution $(250 \mathrm{~mL})$ functioning as artificial plasma $(\mathrm{pH}=7.0 \pm 0.2)$. The artificial plasma during the test had a temperature $T=37.0 \pm 1{ }^{\circ} \mathrm{C}$. Corrosion tests started by determining the open-circuit potential $E_{\mathrm{OCP}}$ for no current flowing. Anodic polarization curves were registered from the initial potential value, $E_{\text {start }}=$ $E_{\mathrm{OCP}}-100 \mathrm{mV}$. The potential change took place in the anodic direction at a speed of $0.16 \mathrm{mV} / \mathrm{s}^{8-10}$ After obtaining an anodic current density of $1 \mathrm{~mA} / \mathrm{cm}^{2}$ or the measurement range $+4000 \mathrm{mV}$, the polarization direction was changed in order to register the formation of any hysteresis loop. Further, electrochemical impedance spectroscopy (EIS) tests were conducted using an AutoLab PGSTAT 302N system equipped with an FRA2 module. The measurement system was used in the frequency range $10^{4}-10^{-3} \mathrm{~Hz}$, with a sinusoidal voltage amplitude of the stimulating signal of $10 \mathrm{mV}$. The impedance spectra were determined and the measurements matched to an equivalent circuit by means of the least-squares method. The impedance spectra of the studied system were presented in the form of Nyquist plots for various frequencies and Bode plots. ${ }^{11}$

The mechanical properties were then tested, with the properties of interest being the adhesion of the layers to the base and their hardness. The adhesion of the layers to the base was tested using the scratch-test method on an open platform equipped with a CSM Micro-CombiTester in compliance with the standard. ${ }^{12}$ The test involved generating a scratch with an indenter (Rockwelltype diamond cone), gradually increasing the load on the indenter. The assessment of the critical load, Lc, was made on the basis of registered acoustic emission changes, friction force and coefficient, as well as observations from the light microscope integrated into the platform. The tests were performed at increasing loads in the range $0.03-20 \mathrm{~N}$ and for the following parameters: load rate $10 \mathrm{~N} / \mathrm{min}$, table speed $1.5 \mathrm{~mm} / \mathrm{min}$, scratch length $\approx 3 \mathrm{~mm}$. The instrumental hardness measurement was performed using the Oliver-Pharr method, with the use of a Berkovich indenter on the open platform Micro-Combi-Tester by CSM Instruments. The loading and unloading rate amounted to $0.40 \mathrm{mN} / \mathrm{min}$, while the loading force exerted on the indenter was 0.20 $\mathrm{mN} .^{13}$

\section{RESULTS}

Polarization curves registered during the potentiodynamic tests were the basis for a determination of the characteristic quantities describing the pitting-corrosion resistance of cpTi with a modified surface layer before and after sterilization (steam and EO) (Figure $\mathbf{1}$ and Table 1). 
The corrosive potential registered for the samples before sterilization assumed the following values: cpTi+ $\mathrm{TiO}_{2}-E_{\text {corr }}=-235 \mathrm{mV}$ and $\mathrm{cpTi}+\mathrm{SiO}_{2}-E_{\text {corr }}=$ $-178 \mathrm{mV}$. In the case of the samples subjected to anodic oxidation and sterilization, the corrosive potential was: cpTi+ $\mathrm{TiO}_{2}+$ steam $-E_{\text {corr }}=-142 \mathrm{mV}$ and cpTi+TiO $2+\mathrm{EO}$ $-E_{\text {corr }}=-170 \mathrm{mV}$, while for the samples coated with silica and sterilized it was: $\mathrm{cpTi}+\mathrm{SiO}_{2}+$ steam $-E_{\text {corr }}=$ $-121 \mathrm{mV}$ and $\mathrm{cpTi}+\mathrm{SiO}_{2}+\mathrm{EO}-E_{\text {corr }}=-121 \mathrm{mV}$. Regardless of the surface-modification method and the medical sterilization method, no hysteresis loop was observed, which shows that the analysed samples polarized up to potential value of $+4000 \mathrm{mV}$ are fully resistant to pitting corrosion (Figure $\mathbf{1}$ and Table 1).

Table 1: Results of potentiodynamic test (mean measurement values) Tabela 1: Rezultati potenciodinamičnega preizkusa (srednje izmerjene vrednosti)

\begin{tabular}{|c|c|c|}
\hline Surface & $E_{\text {corr }}, \mathrm{mV}$ & $R_{\mathrm{p}}, \mathrm{M} \Omega \mathrm{cm}^{2}$ \\
\hline \multicolumn{3}{|c|}{$\mathrm{cpTi}+\mathrm{TiO}_{2}$} \\
\hline inital state & -235 & 4.02 \\
\hline EO & -170 & 43.70 \\
\hline steam & -142 & 30.58 \\
\hline \multicolumn{3}{|c|}{$\mathrm{cpTi}^{-\mathrm{SiO}_{2}}$} \\
\hline inital state & -178 & 0.47 \\
\hline EO & -121 & 9.20 \\
\hline steam & -121 & 1.30 \\
\hline
\end{tabular}
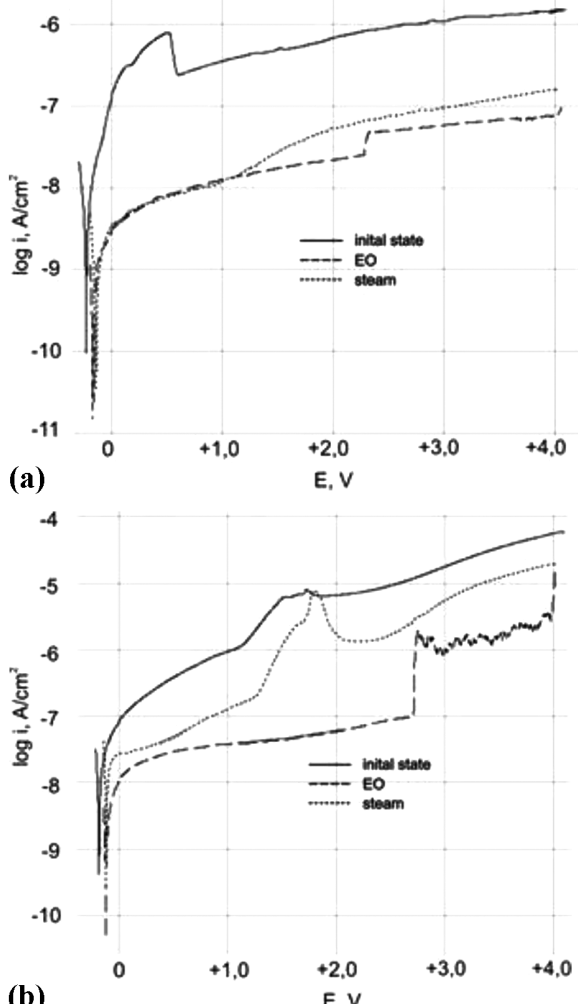

(b)

$E, V$

Figure 1: Anodic polarisation curves of sample: a) cpTi( $\left.\mathrm{TiO}_{2}\right)$, b) $\operatorname{cpTi}\left(\mathrm{SiO}_{2}\right)$

Slika 1: Krivulje anodne polarizacije vzorcev: a) cpTi( $\left.\mathrm{TiO}_{2}\right)$, b) $\operatorname{cpTi}\left(\mathrm{SiO}_{2}\right)$
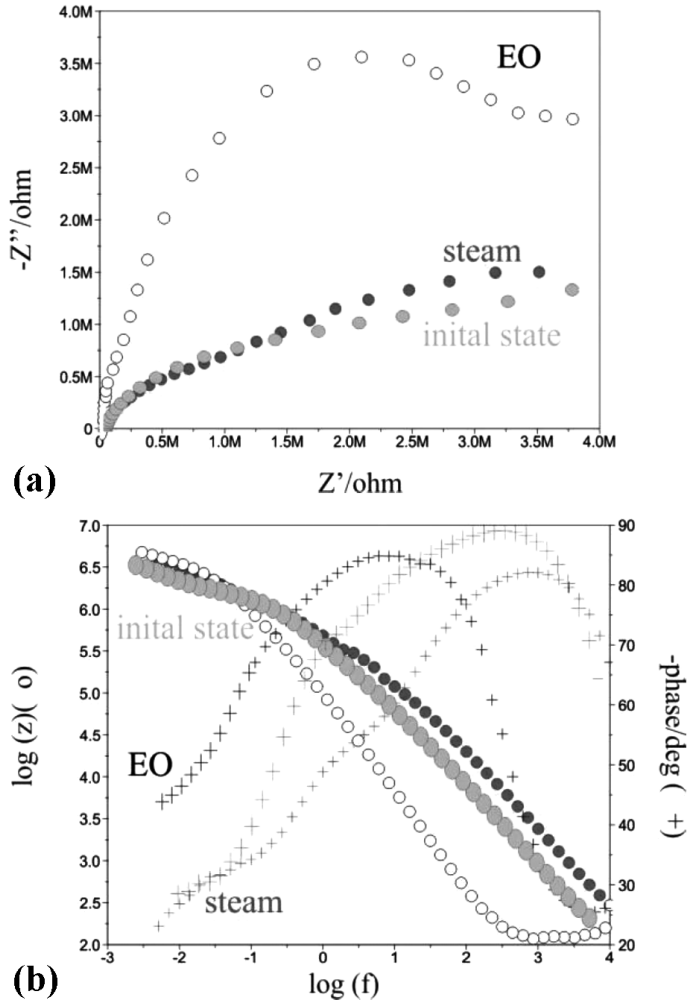

Figure 2: Impedance spectra for the sample cpTi $\left(\mathrm{TiO}_{2}\right)$ : a) Nyquist plot, b) Bode diagram

Slika 2: Spekter impedance za vzorec cpTi( $\left.\mathrm{TiO}_{2}\right)$ : a) Nyquist diagram, b) Bode diagram

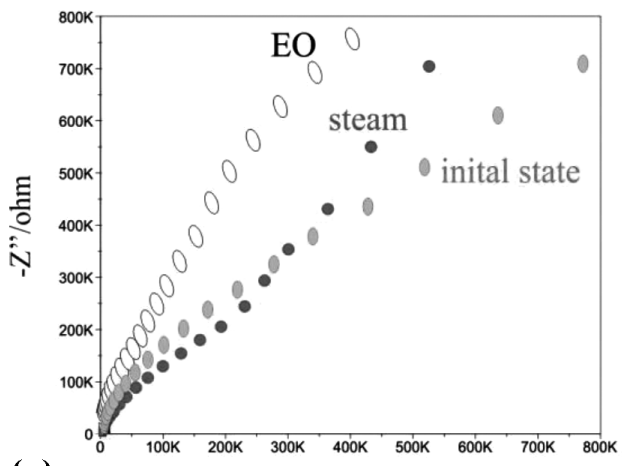

(a)

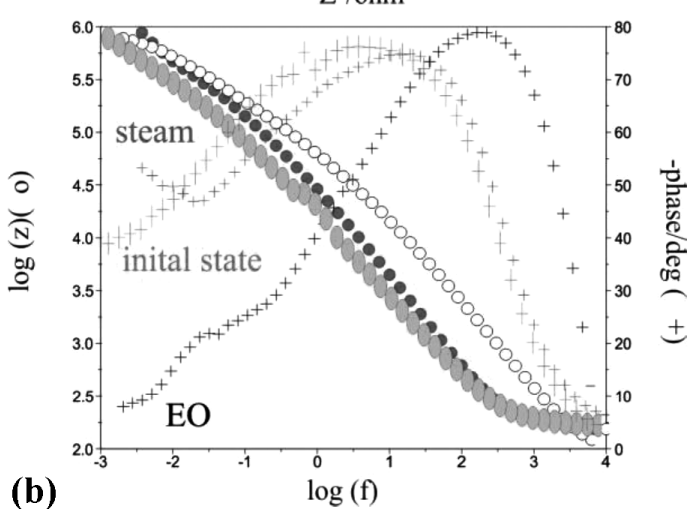

Figure 3: Impedance spectra for the sample $\operatorname{cpTi}\left(\mathrm{SiO}_{2}\right)$ : a) Nyquist plot, b) Bode diagram

Slika 3: Spekter impedance za vzorec cpTi $\left(\mathrm{SiO}_{2}\right)$ : a) Nyquist diagram, b) Bode diagram 
a)

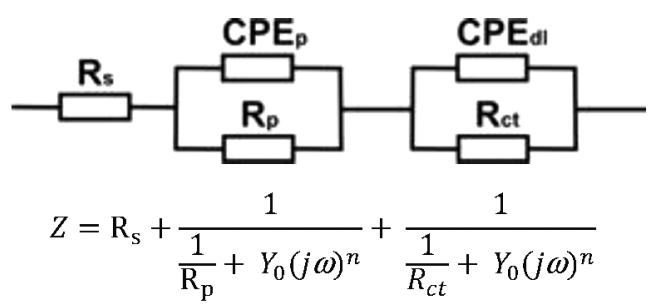

b)

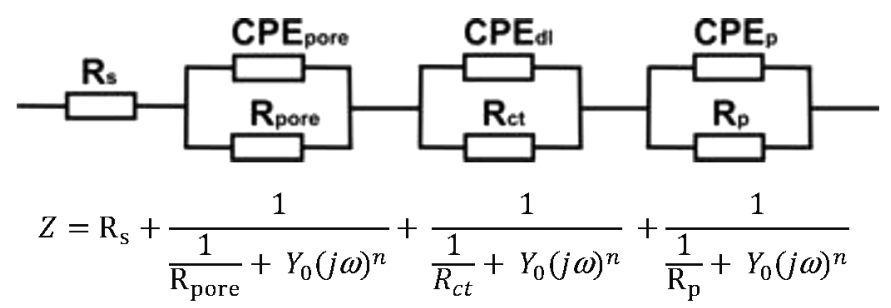

Figure 4: Physical models of an electrical equivalent system for a corrosion system: metal - solution ${ }^{5,6,11}$ Slika 4: Fizikalni modeli ekvivalentnega električnega sistema za korozijski sistem: kovina - raztopina ${ }^{5,6,11}$

Table 2: EIS analysis results

Tabela 2: Rezultati EIS-analize

\begin{tabular}{|c|c|c|c|c|c|c|c|c|c|c|}
\hline \multirow{2}{*}{ Surface } & \multirow{2}{*}{$\begin{array}{c}R_{\mathrm{s}} / \\
\Omega \mathrm{cm}^{2}\end{array}$} & \multirow{2}{*}{$\begin{array}{l}R_{\text {pore }} / \\
\Omega \mathrm{cm}^{2}\end{array}$} & \multicolumn{2}{|c|}{$C P E_{\text {pore }}$} & \multirow{2}{*}{$\begin{array}{c}R_{\mathrm{p}} / \\
\mathrm{k} \Omega \mathrm{cm}^{2}\end{array}$} & \multicolumn{2}{|l|}{$C P E \mathrm{p}$} & \multirow{2}{*}{$\begin{array}{c}R_{\mathrm{ct}} / \\
{\mathrm{M} \Omega \mathrm{cm}^{2}}^{2}\end{array}$} & \multicolumn{2}{|l|}{$C P E_{\mathrm{dl}}$} \\
\hline & & & $Y_{0} / \Omega^{-1} \mathrm{~cm}^{-2} \mathrm{~s}^{-\mathrm{n}}$ & $n$ & & $Y_{0} / \Omega^{-1} \mathrm{~cm}^{-2} \mathrm{~s}^{-\mathrm{n}}$ & $n$ & & $Y_{0} / \Omega^{-1} \mathrm{~cm}^{-2} \mathrm{~s}^{-\mathrm{n}}$ & $n$ \\
\hline \multicolumn{11}{|c|}{ cpTi+ $\mathrm{TiO}_{2}$} \\
\hline inital state & 19 & - & - & - & 968 & $0.2083 \mathrm{E}-6$ & 0.89 & 4.26 & $0.1852 \mathrm{E}-5$ & 0.81 \\
\hline $\mathrm{EO}$ & 18 & - & - & - & 700 & $0.1460 \mathrm{E}-6$ & 0.96 & 4.40 & $0.1901 \mathrm{E}-6$ & 0.93 \\
\hline steam & 18 & 112 & $0.2092 \mathrm{E}-6$ & 0.94 & 817 & $0.5091 \mathrm{E}-6$ & 0.90 & 3.66 & $0.2417 \mathrm{E}-5$ & 0.82 \\
\hline \multicolumn{11}{|c|}{$\mathrm{cpTi}+\mathrm{SiO}_{2}$} \\
\hline inital state & 18 & - & - & - & 188 & $0.6605 \mathrm{E}-5$ & 0.93 & 1.59 & $0.2065 \mathrm{E}-4$ & 0.88 \\
\hline EO & 19 & - & - & - & 224 & $0.1730 \mathrm{E}-5$ & 0.83 & 3.00 & $0.6317 \mathrm{E}-5$ & 0.75 \\
\hline steam & 17 & - & - & - & 160 & $0.9806 \mathrm{E}-5$ & 0.85 & 2.40 & $0.2664 \mathrm{E}-4$ & 0.85 \\
\hline
\end{tabular}

The impedance spectra determined during the EIS tests indicate diversified kinetics during the process taking place in the surface layers formed on the cpTi base before and after medical sterilization (Figures 2 and 3). The impedance spectra were analysed with the use of equivalent circuits, and their resultant impedances described (Figure 4 and Table 2). The best conformity between the model spectra and the experimental spectra obtained from the artificial plasma was achieved in the following circuits: ${ }^{5,6,11}$

- circuit indicating the existence of a double layer, where $R_{\mathrm{s}}$ is the resistance of the artificial plasma, $C P E_{\mathrm{p}}$ is a constant phase element modelling the capacity of the surface zone of the material, with a highly developed surface, $R_{\mathrm{p}}$ - an element modelling the solution resistance in this zone, $R_{\mathrm{ct}}$ and $C P E_{\mathrm{dl}}-$ resistance and capacity of the oxide layer (Figure 4a),

- circuit including also $C P E_{\text {pore }}$ - an element representing the capacity of a double (porous) layer and an $R_{\text {pore }}$ resistor representing the electrolytic resistance in the pores (Figure $\mathbf{4 b}$ ).

In the case of the $\mathrm{cpTi}+\mathrm{TiO}_{2}+$ steam sample, the layer was triple. This was a result of the penetration of the artificial plasma into the surface layer, resulting from the fact that the oxide layer created during anodic oxidation was destroyed by the steam, and recreated deeper inside, up to the layer adjacent to the base. In the remaining samples, the presence of a layer with high surface development was observed. The layer functioned as an additional barrier protecting the material against the corrosive environment.

Table 3: The results of adhesion of the layer on the cpTi substrate

Tabela 3: Rezultati adhezije plasti na podlago iz cpTi

\begin{tabular}{|c|c|c|c|c|c|c|c|}
\hline & \multirow{3}{*}{ Failure of the layer } & \multicolumn{6}{|c|}{ The value of registered indenter load $F \mathrm{n} / \mathrm{N}$} \\
\hline & & \multicolumn{3}{|c|}{$\mathrm{cpTi}+\mathrm{SiO}_{2}$} & \multicolumn{3}{|c|}{$\mathrm{cpTi}+\mathrm{TiO}_{2}$} \\
\hline & & inital state & steam & EO & inital state & steam & EO \\
\hline \multirow[t]{2}{*}{ Measurment 1} & Delamination $L \mathrm{c}_{1}$ & 2.59 & 2.89 & 2.79 & 2.71 & 1.66 & 1.87 \\
\hline & Complete break $L \mathrm{c}_{2}$ & 7.58 & 4.32 & 4.05 & 5.35 & 2.67 & 2.58 \\
\hline \multirow[t]{2}{*}{ Measurement 2} & Delamination $L \mathrm{c}_{1}$ & 3.78 & 3.26 & 1.95 & 2.96 & 1.67 & 1.65 \\
\hline & Complete break $L \mathrm{c}_{2}$ & 5.76 & 4.55 & 2.59 & 4.95 & 2.56 & 2.37 \\
\hline \multirow[t]{2}{*}{ Measurement 3} & Delamination $L \mathrm{c}_{1}$ & 3.38 & 2.41 & 2.01 & 3.33 & 1.82 & 1.78 \\
\hline & Complete break $L \mathrm{c}_{2}$ & 6.16 & 4.88 & 2.89 & 5.08 & 2.89 & 2.12 \\
\hline \multirow[t]{2}{*}{ Average } & Delamination $L \mathrm{c}_{1}$ & 3.25 & 2.85 & 2.25 & 3.00 & 1.71 & 1.76 \\
\hline & Complete break $L \mathrm{c}_{2}$ & 6.50 & 4.58 & 3.08 & 5.12 & 2.70 & 2.35 \\
\hline \multirow{2}{*}{$\begin{array}{l}\text { Standard } \\
\text { deviation }\end{array}$} & Delamination $L \mathrm{c}_{1}$ & \pm 0.60 & \pm 0.42 & \pm 0.46 & \pm 0.31 & \pm 0.09 & \pm 0.11 \\
\hline & Complete break $L \mathrm{c}_{2}$ & \pm 0.95 & \pm 0.28 & \pm 0.77 & \pm 0.20 & \pm 0.16 & \pm 0.23 \\
\hline
\end{tabular}




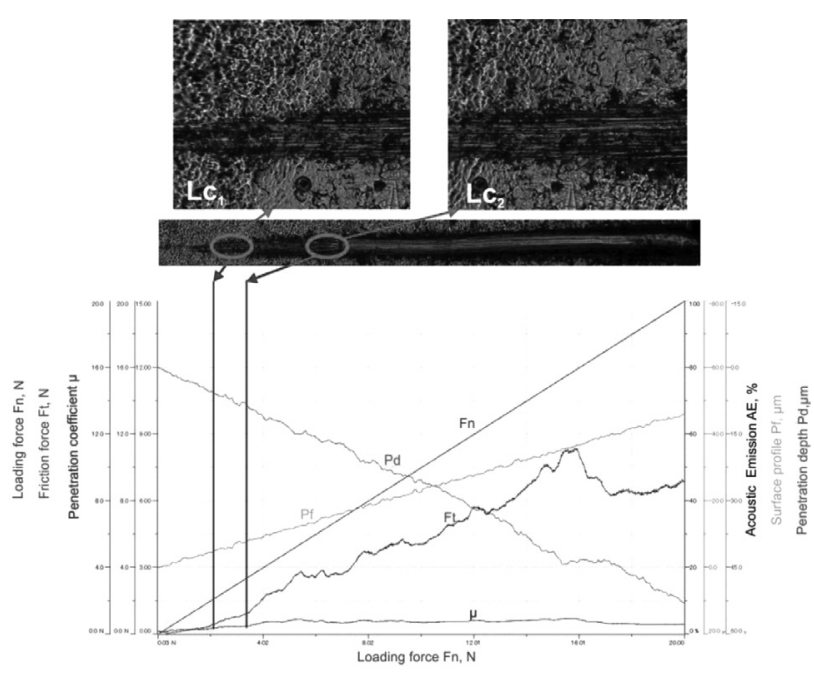

Figure 5: Results of the adhesion tests of the sample cpTi+ $\mathrm{TiO}_{2}+\mathrm{EO}$ Slika 5: Rezultati preizkusa adhezije vzorca cpTi+ $\mathrm{TiO}_{2}+\mathrm{EO}$

The results of the tests of adhesion of the analysed layers to the base material are presented in Table $\mathbf{3}$ and Figures 5 and 6. Regardless of the sterilization method, the results indicate the impairment of adhesion of the layers coated by both anodic oxidation and the sol-gel method in comparison to the baseline samples. This can be seen from the values of the parameters determined on the basis of the measurements (Table 3). It was observed that for the samples not subjected to sterilization, the critical load causing layer delamination inwards and outwards was $L \mathrm{c}_{2}=6.50 \mathrm{~N}$ (cpTi+SiO${ }_{2}$ - sol-gel method) and $L c_{2}=5.12 \mathrm{~N}$ (cpTi+TiO ${ }_{2}-$ anodic oxidation). After sterilization (both steam and EO sterilization), the critical load value decreased to: $L c_{2}=4.58 \mathrm{~N}\left(\mathrm{cpTi}+\mathrm{SiO}_{2}+\right.$ Steam), $L_{c_{2}}=3.08 \mathrm{~N}\left(\mathrm{cpTi}+\mathrm{SiO}_{2}+\mathrm{EO}\right)$ for the sol-gel method, and $L c_{2}=2.70 \mathrm{~N}\left(\mathrm{cpTi}+\mathrm{TiO}_{2}+\right.$ Steam $), L \mathrm{c}_{2}=$ $2.35 \mathrm{~N}\left(\mathrm{cpTi}^{2} \mathrm{TiO}_{2}+\mathrm{EO}\right)$ for the anodic oxidation. Regardless of the type of sample, no acoustic emission signal was registered, which indicated that the bond

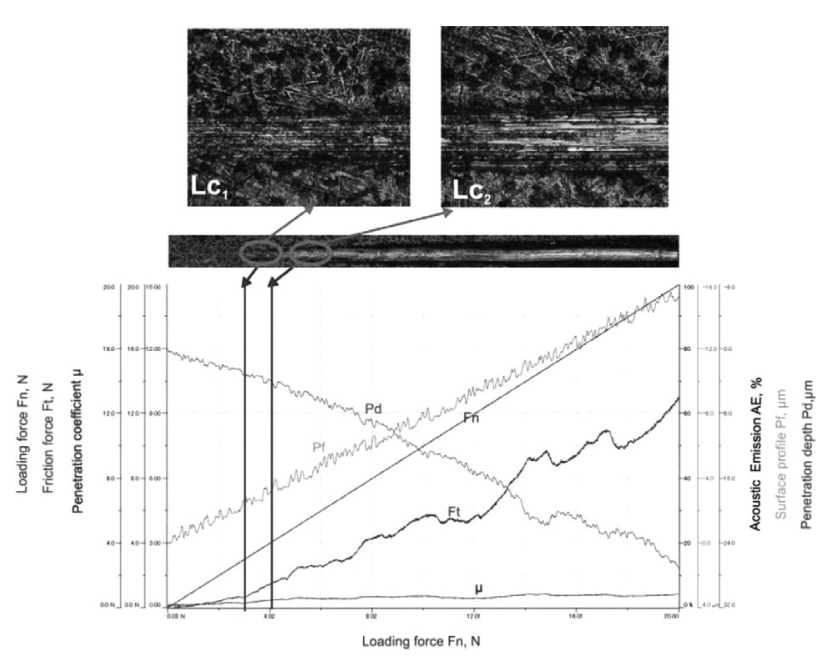

Figure 6: Results of the adhesion tests of the sample cpTi+SiO ${ }_{2}+\mathrm{EO}$ Slika 6: Rezultati preizkusa adhezije vzorca cpTi+SiO + EO energy between the base and the coating was too low. No significant changes between steam and EO sterilization were observed.

The next step involved the hardness testing of the layers. The results of the measurements are shown in Table 4. The results do not show any significant differences between the samples after steam and ethylene oxide sterilization and the baseline samples.

Table 4: The results of nanohardness of the layers

Tabela 4: Rezultati meritve mikrotrdote plasti

\begin{tabular}{|l|c|c|c|c|c|c|}
\hline \multirow{2}{*}{ i.c. } & \multicolumn{5}{|c|}{${\mathrm{Nanohardness} H_{\mathrm{IT}}, \mathrm{MPa}}^{$\cline { 2 - 7 }$}$} & \multicolumn{3}{|c|}{ cpTi+SiO } & \multicolumn{3}{c|}{ cpTi+TiO } \\
\cline { 2 - 7 } & $\begin{array}{c}\text { inital } \\
\text { state }\end{array}$ & steam & EO & $\begin{array}{c}\text { inital } \\
\text { state }\end{array}$ & steam & EO \\
\hline Measurement 1 & 1181 & 1304 & 1082 & 1236 & 1434 & 1171 \\
\hline Measurement 2 & 1236 & 1278 & 923 & 913 & 1247 & 1241 \\
\hline Measurement 3 & 1021 & 1189 & 1120 & 1021 & 1156 & 1089 \\
\hline Average & 1146 & 1257 & 1041 & 1056 & 1279 & 1167 \\
\hline $\begin{array}{l}\text { Standard } \\
\text { deviation }\end{array}$ & \pm 152 & \pm 60 & \pm 104 & \pm 164 & \pm 141 & \pm 76 \\
\hline
\end{tabular}

\section{CONCLUSIONS}

The correct selection of physical and chemical properties is a significant issue in the process of adjusting the functionalities of cardiac implants, ${ }^{14}$ and has a direct impact on the final quality of medical devices. Physical and chemical devices are shaped by means of various types of metal finishing. ${ }^{14,15}$ The influence of various types of titanium alloy finishing on orthopaedic implants has been demonstrated by Szewczenko et al. ${ }^{16}$. He has shown that the method of base preparation has a crucial influence on the physical and chemical properties of the anodic oxide coating. Paszenda has proposed chemical surface modifications of the Cr-Ni-Mo steel intended for cardiac implants in order to achieve a higher hemocompatibility. ${ }^{17}$ The literature review indicates that there are no comprehensive works devoted to a possible change of properties during medical sterilization. ${ }^{18-20}$ Therefore, the authors of this paper focused on an assessment of the possible changes to the mechanical and electrochemical properties of a coating subjected to pressurized steam sterilization and ethylene oxide sterilization. The tests on the samples following medical sterilization processes have shown differences in relation to those samples that did not undergo sterilization. Pressurized-steam sterilization caused a change in the corrosive potential value towards positive values and increased the polarization resistance, regardless of the surface-modification method. For the $\mathrm{TiO}_{2}$-coated samples, it stopped the diffusion processes stemming from the anodic oxidation and caused the formation of an additional layer with a highly developed surface, which functioned as an additional barrier protecting the material against the corrosive environment and increasing the ion-transfer resistance. In the case of the $\mathrm{SiO}_{2}$ layer, this type of sterilization did not cause significant changes to 
the corrosive resistance of cpTi. The mechanical properties, on the other hand, remained unchanged, regardless of the type of metal finishing. However, the adhesion to the base was weaker in comparison to those samples not subjected to sterilization, which may be caused by the restructuring of the surface oxides under the influence of a sterilizing agent, which has a direct impact on the strength of the bonds between the chemical compounds, such as between $\mathrm{TiO}_{2} / \mathrm{Ti}_{2} \mathrm{O}_{3}$ and the base. Ethylene oxide sterilization of the samples with a modified surface also caused changes to their electrochemical and mechanical properties. As in the case of pressurized-steam sterilization, the samples coated with $\mathrm{TiO}_{2}$ and $\mathrm{SiO}_{2}$ had a better resistance to corrosion in contact with the artificial plasma. On the surface of the samples coated with $\mathrm{TiO}_{2}$, the presence of an additional porous layer has been observed. This is the result of the partial degradation of the oxide layer and an increase in its porosity, which, as a consequence, leads to much weaker adhesion to the base. In the scratch test, a decrease in the critical load causing delamination of the layer towards the base was observed.

In conclusion, the study has shown the significant influence of medical sterilization on the physical and chemical properties of the $\mathrm{TiO}_{2}$ and $\mathrm{SiO}_{2}$ layers. It has been proved that, regardless of the surface layer type, the choice of the sterilizing method is an important issue. A $\mathrm{SiO}_{2}$ layer applied with the sol-gel method exhibited a higher electrochemical stability. In the future, the authors plan further work to help identify the chemical composition and chemical compounds formed as a result of the sterilization processes and possible changes to the layer thickness.

\section{Acknowledgements}

The project was funded by the National Science Centre allocated on the basis of the decision No. 2011/03/B/ST8/06499.

\section{REFERENCES}

${ }^{1}$ P. Karasiński, Opt. Appl., 35 (2005), 117-128

${ }^{2}$ J. Szewczenko, J. Jaglarz, M. Basiaga, J. Kurzyk, E. Skoczek, Prz. Elektrot., 88 (2012) 12B, 228-231

${ }^{3}$ A. Sadeq, Z. Cai, R. D. Woody, A. W. Miller, J. Prosth. Dent., 90 (2003) 1, 10-17, doi:10.1016/S0022-3913(03)00263-4

${ }^{4}$ B. Surowska, J. Bieniaś, M. Walczak, K. Sangwal, A. Stoch, Appl. Surf. Sci., 238 (2004), 288-294, doi:10.1016/j.apsusc.2004.05.219

${ }^{5}$ M. Basiaga, W. Walke, Z. Paszenda, P. Karasiński, J. Szewczenko, Biomatt., 4 (2014), 1-6, doi:10.4161/biom.28535

${ }^{6}$ M. Basiaga, Z. Paszenda, W. Walke, P. Karasiński, J. Marciniak, Inf. Technol. Biomed., 284 (2014), 411-420, doi:10.1007/978-3319-06596-0_39

${ }^{7}$ W. Walke, Z. Paszenda, M. Basiaga, P. Karasiński, M. Kaczmarek, Inf. Technol. Biomed., 284 (2014), 403-410, doi:10.1007/9783-319-06596-0_38

${ }^{8}$ ASTM F2129-08 Standard Test Method for Conducting Cyclic Potentiodynamic Polarization Measurements to Determine the Corrosion Susceptibility of Small Implant Devices, 2008, doi:10.1520/F2129-08

${ }^{9}$ W. Kajzer, A. Kajzer, Prz. Elektrot., 12 (2013), 275-279

${ }^{10}$ A. Kajzer, W. Kajzer, J. Semenowicz, A. Mroczka, Sol. St. Phen., 227 (2015), 523-526, doi:10.4028/www.scientific.net/SSP.227.523

${ }^{11}$ M. Kaczmarek, W. Walke, Z. Paszenda, Prze. Elektrot., 12b (2011), 74-77

${ }^{12}$ PN-EN 1071-3. Advanced technical ceramics. Determination of adhesion and other mechanical failure modes by a scratch test, 2007

${ }^{13}$ EN ISO 14577-1 Metallic materials-Instrumented indentation test for hardness and materials parameters-Part1: Test method, 2015

${ }^{14}$ J. Głuszek, Inż. Mat., 5 (2002), 351-354

${ }^{15}$ L. Gan, J. Wang, A. Tache, N. Valiquette, D. Deporter, R. Pilliar, Biomat., 25 (2004), 5313-5321, doi:10.1016/j.biomaterials.2003. 12.039

${ }^{16}$ J. Szewczenko J. Jaglarz, M. Basiaga, J. Kurzyk, Z. Paszenda, Optica Applicata, 43 (2013) 1, 173-180, doi:10.5277/oa130121

${ }^{17}$ Z. Paszenda, Inf. Tech. Biomed., Adv. Soft Comp., 47 (2008), 15-27, doi:10.1007/978-3-540-68168-7_2

${ }^{18}$ N. Kuromoto, R. Simao, G. Soares, Materials Characterization, 58 (2007), 114-121, doi:10.1016/j.matchar.2006.03.020

${ }^{19}$ B. Yang, M. Uchida, H. M. Kim, X. Zhang, T. Kokubo, Biomat, 25 (2004), 1003-1010, doi:10.1016/S0142-9612(03)00626-4

${ }^{20}$ H. Song, S. Park, S. Jeong, Y. Park, Journal of Mater. Proc. Techn., 209 (2009), 864-870, doi:10.1016/j.jmatprotec.2008.02.055 